\title{
MELINDUNGI SUMBER DAYA GENETIK DAN PENGETAHUAN TRADISIONAL DENGAN HAK PATEN DAN HAK MEREK
}

\author{
Triayu Ratna Dewi ${ }^{1}$, Erma Defiana Putriyanti ${ }^{1}$ \\ ${ }^{1}$ Program Studi Ilmu Hukum, Universitas Nasional \\ email : triayudewipatent@gmail.com, erma.defiana@civitas.unas.ac.id.
}

Korespondensi : triayudewipatent@gmail.com

\begin{abstract}
Protecting traditional knowledge is an important issue in Indonesia, this is because there are economic benefits resulting from the use of traditional knowledge and the means to protect the rights of local communities. In connection with the economic benefits generated from the use of traditional knowledge. Indonesia as one of the countries that have the potential for genetic resources and traditional knowledge has not been able to fully enjoy the economic benefits of the utilization of these resources. Therefore this paper aims to examine how to protect genetic resources and traditional knowledge with patents and brand rights. This type of research is analytical descriptive with normative juridical methods and uses qualitative data processing techniques. The results of this study indicate that protecting genetic resources and traditional knowledge with patents is seen in Law number 13 of 2016 concerning Patents, specifically Article 26 paragraph (1), (2) and (3) as well as in the Minister of Law and Human Rights Regulation Republic of Indonesia No. 38 of 2018 concerning Patent Applications, specifically Article 24 paragraphs (1), (2) and (3). The regulation stipulates that if the invention is related to and / or originates from genetic resources and / or traditional knowledge, it must be clearly and correctly stated the origin of such genetic resources and / or traditional knowledge in the description. Protecting genetic resources and traditional knowledge with trademark rights can also be seen in Government Regulation of the Republic of Indonesia Number 22 of 2018 concerning International Trademark Registration Based on Protocol Related to the Madrid Agreement. This policy is an effort to preserve and maintain the continuity of local herbal products so that they can be equal and win the trust of international consumers.
\end{abstract}

Keywords: protect, genetic resources, traditional knowledge, patent rights, trademark rights

\begin{abstract}
Abstrak
Melindungi pengetahuan tradisional menjadi isu penting di Indonesia, hal ini disebabkan karena ada keuntungan ekonomis yang dihasilkan dari pemanfaatan pengetahuan tradisional dan adanya sarana untuk melindungi hak masyarakat lokal. Sehubungan dengan keuntungan ekonomis yang dihasilkan dari pemanfaatan pengetahuan tradisional, Indonesia sebagai salah satu negara yang memiliki potensi sumber daya genetik dan pengetahuan tradisional ternyata belum mampu menikmati seutuhnya hasil pemanfaatan secara ekonopemanfaatan sumber daya tersebut secara ekonomi. Oleh sebab itu penulisan ini bertujuan untuk mengkaji
\end{abstract}


bagaimana cara melindungi sumber daya genetik dan pengetahuan tradisional dengan hak paten dan hak merek. Tipe Penelitian ini bersifat deskriptif analitis dengan metode yuridis normatif dan menggunakan teknik pengolahan data secara kualitatif. Hasil penelitian ini menunjukkan bahwa melindungi sumber daya genetik dan pengetahuan tradisional dengan Hak Paten terlihat dalam Undang-Undang Nomor 13 tahun 2016 tentang Paten, khususnya Pasal 26 ayat (1), (2), dan (3) serta dalam Peraturan Menteri Hukum dan HAM Republik Indonesia No. 38 Tahun 2018 tentang Permohonan Paten, khususnya Pasal 24 ayat (1), (2) dan (3). Peraturan tersebut menentukan bahwa jika invensi berkaitan dan/ atau berasal dari sumber daya genetik dan/ atau pengetahuan tradisional, harus disebutkan dengan jelas dan benar asal sumber daya genetik dan/ atau pengetahuan tradisional tersebut dalam deskripsi. Melindungi sumber daya genetik dan pengetahuan tradisional dengan Hak Merek juga terlihat dalam Peraturan Pemerintah Republik Indonesia Nomor 22 Tahun 2018 Tentang Pendaftaran Merek Internasional Berdasarkan Protokol Terkait dengan Persetujuan Madrid. Kebjiakan tersebut merupakan suatu upaya untuk melestarikan dan menjaga kelangsungan produk jamu lokal agar bisa setara dan mendapat kepercayaan dari konsumen internasional.

Kata kunci: melindungi, sumber daya genetik, pengetahuan tradisional, hak paten, hak merek

\section{PENDAHULUAN}

Keikutsertaan Indonesia dalam convention on biological diversity (CBD) di tahun 1992 menumbuhkan kesadaran dan minat untuk melindungi pengetahuan tradisional. Sejak saat itu berbagai pertemuan tingkat dunia terutama dalam kerangka World Intellectual Property organization (WIPO) terus diselenggarakan untuk merumuskan sistem pelindungan yang tepat bagi pengetahuan tradisional (Undang-Undang No. 5 Tahun 1994).

Melindungi pengetahuan tradisional menjadi isu penting di Indonesia, hal ini disebabkan karena 2 alasan yaitu:

1. Ada keuntungan ekonomis yang dihasilkan dari pemanfaatan pengetahuan tradisional

2. Adanya sarana untuk melindungi hak masyarakat lokal (Sardjono, 2010).

Sehubungan dengan keuntungan ekonomis yang dihasilkan dari pemanfaatan pengetahuan tradisional, Indonesia sebagai salah satu negara yang memiliki potensi sumber daya genetik dan pengetahuan tradisional ternyata belum mampu seutuhnya menikmati secara ekonomi atas hasil dari pemanfaatan sumber daya tersebut, ironisnya justru negara maju seperti Jepang dan Amerika Serikat yang memperoleh manfaat ekonomi dari sumber daya genetik dan pengetahuan tradisional tersebut. Sebagai salah satu contoh, dalam penelusuran data paten melalui jaringan Europe Patent, diketahui bahwa 45 jenis obat penting yang dipatenkan oleh Amerika Serikat, 14 jenis diantaranya berasal dari tumbuhan asli Indonesia, seperti tumbuhan "tapak dara" yang berfungsi sebagai obat kanker (Kompas, 2002). Di Jepang juga tercatat ada pemberian hak paten atas obat-obatan yang bahannya bersumber dari biodiversity dan pengetahuan tradisional Indonesia. Hal ini membuktikan bahwa meskipun Indonesia merupakan sumber dari keanekaragaman genetik yang dapat dijadikan bahan baku pembuatan obat, 
Indonesia sama sekali tidak memperoleh keuntungan ekonomi dari sumber daya genetik tersebut.

Bagi masyarakat lokal, pengunaan bahan baku genetik sebagai ramuan obat merupakan pengetahuan tradisional yang telah diwariskan pengunaannya secara turun temurun sehingga terkadang mereka menganggap itu merupakan suatu hal yang biasa. Kecenderungan dari masyarakat Indonesia yang awam dan kurang memahami rezim pelindungan Hak Kekayaan Intelektual (HKI) dalam bentuk hak paten dan hak merek, menyebabkan nilai ekonomi dari pemanfaatan pengetahuan tradisional menjadi terabaikan. Padahal pemanfaatan ekonomi dari sumber daya genetik dan pengetahuan tradisional dapat difungsikan untuk meningkatkan pendapatan individu maupun kelompok masyarakat melalui sistem lisensi (TS, Utomo et al, 2006).

Perlu diakui bahwa negara-negara berkembang seperti Indonesia hanya memiliki sumber daya genetik, sedangkan negara maju memiliki kemapanan teknologi dan kemampuan SDM. Mereka menggunakan sumber daya genetik dan pengetahuan tradisional melalui suatu informasi yang diperoleh melalui sebuah riset di suatu negara tanpa melibatkan negara asal sebagai sumber perolehan sumber daya genetik dan pengetahuan tradisional tersebut secara langsung. Menurut pendapat penulis, hal tersebut merupakan suatu bentuk ketidakadilan. Hal Ini sama dengan melakukan pencurian secara nyata atas sumber daya genetik dan pengetahuan tradisional yang nampaknya tidak disadari oleh masyarakat lokal.

Menelusuri ulang konsep keadilan, menurut teori kegunaan (utility theory) dalam aliran utilitarianisme (Rasjidi, 2004) yang dipelopori oleh Jeremy Bentham, menyatakan bahwa hukum harus memberikan kebahagian sebesar-besarnya bagi individu baru maupun orang banyak. Artinya bahwa keadilan itu dapat tercapai apabila peraturan yang dibuat bisa memberikan pelindungan, kelangsungan hidup dan persamaan. Hak kekayaan intelektual merupakan sistem hukum yang diciptakan oleh negara-negara Common Law yang mengedepankan pada prinsip kapitalisme dan monopoli, namun dalam perkembangan HKI modern dewasa ini, prinsip tersebut mulai luntur mengingat era perdagangan ekonomi yang berkembang saat ini lebih ke arah pembagian keuntungan (Profit Sharing). Meskipun beberapa pakar mengatakan bahwa pelindungan atas sumber daya genetik dan pengetahuan tradisional tidak masuk dalam ranah pelindungan HKI dan harus dibuat dalam peraturan tersendiri, namun faktanya sejauh ini hanya peraturan HKI yang bisa menjamin keberlangsungan dari pengetahuan tradisional tersebut. Pada penulisan ilmiah ini penulis akan mencoba untuk menjelaskan mengenai cara menjaga keberlangsungan sumber daya genetik dan pengetahuan tradisional melalui konsep pelindungan hak paten dan hak merek.

\section{Pokok Permasalahan}

Berkenaan dengan penjelasan tersebut diatas, adapun pokok permasalahan dalam penulisan karya ilmiah ini adalah sebagai berikut:

1. Bagaimana cara melindungi sumber daya genetik dan pengetahuan tradisional dengan hak paten? 
2. Bagaimana cara melindungi sumber daya genetik dan pengetahuan tradisional dengan hak merek?

\section{METODE PENELITIAN}

Penelitian ini bersifat deskriptif analitis dengan metode yuridis normatif. Metode yuridis normatif adalah metode pendekatan yang didasarkan pada penelitian kepustakaan yang berupa pengkajian dan pengolahan data sekunder yang meliputi peraturan perundang-undangan, baik peraturan nasional maupun peraturan internasional, yurisprudensi, jurnal, literature dan artikel lain yang relevan. Data yang diperoleh dalam penelitian ini disusun secara sistematis dan dianalisis dengan metode kualitatif. Metode kualitatif yaitu metode pengumpulan dan penyeleleksian data yang diperloleh dari data sekunder. Selanjutnya, hasil dari penyusunan data diperoleh jawaban atas permasalahan yang diajukan. Lebih lanjut data tersebut dituangkan dalam bentuk uraian yang bersifat deskriptif kualitatif, yaitu suatu uraian yang menggambarkan permasalahan serta pemecahannya secara jelas dan lengkap berdasarkan data-data yang diperoleh dari penelitian (Aini, 2010).

\section{PEMBAHASAN}

\section{Sumber Daya Genetik dan Pengetahuan Tradisional Dalam Konsep WIPO}

Secara umum pengetahuan tradisional diartikan sebagai pengetahuan yang dikembangkan oleh masyarakat pribumi atau karya intelektual berdasarkan tradisi. World Intellectual Property Organization (WIPO) memberikan definisi pengetahuan tradisional sebagai berikut :

"Knowledge, know-how, skills and practices that are developed, sustained and passed on from generation to generation within a community, often forming part of its cultural or spiritual identity". Traditional knowledge (TK) is a living body of knowledge passed on from generation to generation within a community. It often forms part of a people`s cultural and spiritual identity. WIPO's program on TK also addresses genetic resources (GRs) and traditional expressions (TCEs)".

Menurut Prof. Agus Sardjono mendefinisikan pengetahuan tradisional sebagai pengetahuan yang dimiliki atau dikuasai dan digunakan oleh suatu komunitas, masyarakat, atau suku bangsa tertentu yang bersifat turun temurun dan berkembang sesuai dengan perubahan lingkungan (Sardjono 2010). Dengan demikian secara sederhana pengetahuan tradisional digambarkan sebagai pengetahuan yang menjadi bagian identitas budaya atau spiritual dari suatu komunitas, masyarakat, atau suku bangsa tertentu yang didapatkan secara turun temurun.

Pengetahuan tradisional menurut WIPO diklasifikasikan menjadi: pengetahuan pertanian (agricultural knowledge), pengetahuan ilmiah (scientific knowledge), pengetahuan lingkungan (ecological knowledge), pengetahuan obatobatan termasuk di dalamnya obat dan penyembuhan (medicines knowledge including related medicine and remedies), pengetahuan terkait keanekaragaman 
genetic (biodiversity-related knowledge). Adapun definisi pendekatan terhadap pengertian pengetahuan tradisional cakupannya sangat luas karena meliputi juga unsur foklor, namun dalam penulisan karya ilmiah ini, penulis tidak membahas lebih lanjut soal pengetahuan tradisional terkait ekspresi budaya, pembahasan ini hanya fokus kepada persoalan keanekaragaman genetik yang mengangkat pengetahuan tradisional milik masyarakat Indonesia.

Pada prinsipnya upaya untuk melindungi pengetahuan tradisional sebagai hak komunal memang mulai dilakukan melalui mekanisme WIPO yaitu dengan membentuk WIPO Fact-finding Missions (WIPO-FFMs) dan The WIPO Intergovernmental Committee (IGC) on Intellectual Property and Genetic Resources, Traditional Knowledge and Folklore. maupun melalui pembentukan konvensi internasional yang melahirkan Nagoya Protocol on Access to Genetic Resources and the Fair and Equitable Sharing of Benefits Arising from their Utilization to the Convention on Biological Diversity yang diadopsi pada tanggal 29 Oktober 2010 di Nagoya. Namun demikian, negara-negara maju antara lain Perancis, Jepang, Belanda, Inggris, dan Amerika Serikat secara nyata menolak mengakui adanya kepemilikan komunal sebagai suatu kolektivitas, terutama ketika membicarakan The Draft United Nations Declaration on the Rights of Indigenous Peoples. Berdasarkan penjelasan tersebut menunjukkan bahwa WIPO berupaya untuk menempatkan pengetahuan tradisional ke dalam peraturan tersendiri di luar HKI, namun masih menggantung. Hal ini dikarenakan tidak mendapat dukungan dari negara-negara maju. Di Indonesia, Rancangan Undang-Undang tentang Pengetahuan tradisional dan Ekspresi Budaya tradisional tidak kunjung di sahkan sebagai Undang-Undang, sehingga menurut pendapat penulis, sarana yang bisa digunakan untuk melindungi dan menjaga keberlangsungan dari produk hasil pengetahuan tradisional tetap melalui mekanisme sistem paten dan merek.

\section{Melindungi Sumber Daya Genetik dan Pengetahuan Tradisional dengan Hak Paten}

Menurut Pasal 1 ayat (1) Undang-undang No. 13 Tahun 2016. Paten adalah hak eksklusif yang diberikan oleh negara kepada inventor atas hasil invensinya di bidang teknologi untuk jangka waktu tertentu melaksanakan sendiri invensi tersebut atau memberikan persetujuan kepada pihak lain untuk melaksanakannya. Hak eksklusif atas paten ini, bisa diperoleh inventor apabila permohonan patennya mendapat persetujuan (granted) dari negara penerima paten, artinya apabila negara yang mendapat pengajuan permohonan paten itu menolak permohonan patennya maka secara otomatis kepemilikan hak eksklusifnya hilang. Perlu diketahui bahwa bentuk pelindungan HKI sifatnya teritorial, jika inventor ingin mendapat hak eksklusif atas patennya di negara lain, maka inventor harus mengajukan permohonan pelindungan hak patennya ke negara tersebut. Perlu di ingat juga bahwa tidak semua permohonan paten dapat di terima, terdapat berbagai tahapan pemeriksaan paten yang harus dilalui sebelum hak patennya diberikan oleh negara tersebut.

Hak paten hanya diberikan atas hasil invensi di bidang teknologi. Pada prinsipnya segala macam invensi dapat dipatenkan dengan syarat invensi tersebut 
baru dan memang belum pernah ada dalam lapangan teknologi yang bersangkutan. Paten memang erat kaitannya dengan teknologi. Di negara maju, peran teknologi menjadi perhatian utama dalam menjawab permasalahan ekonomi dan meningkatkan daya saing.

Tantangan ekonomi ke depan adalah bagaimana negara tersebut mampu survive dalam mengembangkan suatu inovasi secara konsisten dan berkelanjutan. Hal tersebut dapat dilakukan melalui pembentukan lembaga penelitian pemerintah, swasta, pemanfaatan sumber daya alam, pemberdayaan SDM, sistem jaringan informasi penelitian, pengembangan dan penerapan teknologi di bidang-bidang strategis dalam bentuk publikasi ilmiah, layanan teknologi maupun wirausahawan teknologi.

Menjawab tantangan tersebut, Indonesia sebagai negara yang memiliki sumber daya genetik dan pengetahuan tradisional sering dimanfaatkan dan tidak dilibatkan oleh inventor luar negeri untuk menghasilkan invensi baru. Permasalahan lain yang perlu diperhatikan dalam upaya melindungi sumber daya genetik dan pengetahuan tradisional dengan Hak Paten adalah bahwa faktanya Indonesia tidak memiliki database atas asset-aset sumber daya genetik dan pengetahuan tradisional asli bangsa Indonesia, sehingga memudahkan sekali pencurian. Selain itu kemampuan SDM dalam negeri untuk mengembangkan inovasi atau riset dari pengetahuan tradisional dan biaya pengurusan hak paten yang mahal seringkali menjadi kendala.

Melalui Pasal 26 ayat (1) Undang-undang No. 13 Tahun 2016 Tentang Paten, Pemerintah telah menerapkan suatu kebijakan di bidang pembaharuan hukum perihal penggunaan invensi yang berkaitan dengan sumber daya genetik dan pengetahuan tradisional harus disebutkan secara jelas dan benar apabila bahan yang dipergunakan dalam invensi berkaitan pada sumber daya genetik atau pengetahuan tradisional Indonesia dalam deskripsi pengajuan permohonan paten. Selain itu masih di pasal yang sama di ayat (3), pemerintah menerapkan adanya syarat pembagian hasil atas akses pemanfaatan dan pengunaan sumber daya genetik sebagaimana dimaksud melalui mekanisme peraturan perundang-undangan dan perjanjian internasional di bidang sumber daya genetik dan pengetahuan tradisional.

Sebagai pelaksanaan Undang-undang tersebut, maka Pemerintah mengeluarkan Peraturan Menteri Hukum dan HAM Republik Indonesia No. 38 Tahun 2018 Tentang Permohonan Paten. Pasal 24 ayat (1) mengatur bahwa permohonan paten yang berasal atau berkaitan dengan sumber daya genetik dan pengetahuan tradisional harus disebutkan dengan jelas dan benar dalam deskripsi paten. Dalam ayat (2) ditentukan bahwa informasi tentang pengetahuan tradisional yang dimaksud di tetapkan oleh lembaga resmi yang diakui oleh pemerintah, sedangkan dalam ayat (3) dipertegas dengan ketentuan yang mewajibkan Pemohon paten untuk membuat surat pernyataan yang menyatakan kebenaran dan kejelasan asal sumber daya genetik dan pengetahuan tradisional tersebut.

Terkait dengan peraturan sebagaimana yang telah penulis utarakan di atas, maka sudah sewajarnya apabila Indonesia merasa berhak dan mendapatkan imbalan (royalty) atas penggunaan sumber daya genetik dan pengetahuan tradisionalnya dari inovasi inventor asing. Prakteknya seringkali inventor asing yang sudah memperoleh 
hak paten di Indonesia tidak mau membayar biaya pemeliharaan atas patennya sehingga kemudian kepemilikan hak patennya di hapus oleh pemerintah Indonesia. Penulis berpendapat bahwa dengan dihapusnya kepemilikan atas paten yang belum jatuh tempo pelindungan sebenarnya merupakan kesempatan bagi inventor dalam negeri untuk melakukan pengembangan ulang atas inovasi dari paten sebelumnya. Adapun bentuk pengembangan ulang sebagaimana di maksud bisa dalam wujud paten sederhana (Utility Model).

Dibutuhkan kemampuan dari para peneliti maupun inventor Indonesia dalam mengembangkan inovasi ulang atas suatu paten yang berasal dari suatu sumber daya genetik dan pengetahuan tradisional Indonesia. Tindakan tersebut merupakan suatu langkah efektif untuk memperoleh pembaharuan hak paten yang selanjutnya bisa dijual atau di lisensikan penggunaannya dalam kurun waktu tertentu, sehingga turut berkontribusi dalam peningkatan ekonomi serta turut menjaga keberlangsungan kepemilikan masyarakat lokal.

\section{Melindungi Sumber Daya Genetik dan Pengetahuan Tradisional dengan Hak Merek}

Merek merupakan salah satu bagian dari HKI yang dapat dilindungi. Sama halnya dengan bentuk pelindungan HKI lainnya, pelindungan atas merek bersifat teritorial. Secara garis besar merek erat kaitannya dengan pelindungan atas suatu penamaan dan logo yang berfungsi untuk membedakan dan mengidentifikasi produk tertentu karena karakteristiknya (Indriyanto, 2017), oleh karena itu terkadang merek dilihat sebagai bentuk pelindungan terhadap identitas asal produksi dalam hubungannya dengan konsumen.

Merek dapat menjadi insentif untuk menjaga kualitas produk secara konsisten karena merek bertindak sebagai jaminan kepada konsumen ${ }^{15}$. Jika produsen dari suatu merek menurunkan kualitasnya maka risiko yang diterima berupa hilangnya konsumen. Masyarakat awam seringkali mempersamaan istilah penggunaan merek dengan brand padahal ditinjau dari segi legalitasnya, penggunaan nama merek dan brand sangatlah berbeda. Nama dagang (Brand) sifatnya masih umum artinya siapapun bebas mempergunakan nama itu, sedangkan merek (Trademark) merupakan nama merek yang sudah terdaftar kepemilikannya.

Terkait dengan masalah kepemilikan, Pasal 1 ayat (5) Undang-Undang No. 20 Tahun 2016 Tentang Merek dan Indikasi Geografis menyebutkan Hak atas merek adalah hak eksklusif yang diberikan oleh negara kepada pemilik merek terdaftar selama jangka waktu tertentu mengunakan sendiri merek tersebut dan memberikan izin kepada pihak lain untuk menggunakannya.

Penggunaan nama merek bisa diterapkan ke dalam semua produk yang diperdagangkan baik itu produk barang maupun jasa. Adapun merek lokal asli Indonesia yang berbasis pada warisan pengetahuan tradisional yang telah dikemas secara modern dan di produksi secara massal adalah produk jamu yang cukup kita kenal dengan merek dagang "Nyonya Meener, Sido Muncul, Kuku Bima" dan lain sebagainya. Keberadaan dari merek- merek tersebut menunjukkan eksistensi dari pemanfaatan sumber daya genetik dan pengetahuan tradisional ke dalam industri jamu. 
Tiongkok merupakan salah satu negara yang berhasil menyebarluaskan dan mempertahankan eksistensi pengetahuan ramuan obat tradisionalnya dalam bentuk merek obat Cina, tidak hanya dalam bentuk merek dagang obat Cina namun termasuk pula merek dagang toko obat Cina yaitu "Beijing To Ren Tang" yang cukup terkenal dan beraset mahal. Ramuan pengobatan Cina dianggap berkhasiat dan manjur karena menggunakan bahan baku herbal dan memiliki kualitas tersendiri yang mampu dipertahankan oleh produsennya, apalagi di tambah dengan terdaftarnya merek tersebut di WIPO sebagai merek internasional.

Indonesia sebagai salah satu pemilik sumber daya genetik dan pengetahuan tradisional sebenarnya bisa melakukan hal yang serupa, memperkenalkan ramuan pengetahuan tradisionalnya dalam wujud pelindungan merek. Dengan di ratifikasinya sistem pendaftaran merek internasional yang dituangkan dalam bentuk Peraturan pemerintah Republik Indonesia Nomor 22 Tahun 2018 Tentang Pendaftaran Merek Internasional Berdasarkan Protokol Terkait dengan Persetujuan Madrid, merupakan suatu langkah pembaharuan hukum yang bertujuan untuk memperkenalkan merek yang berasal dari pengetahuan tradisional Indonesia ke ranah global. Kebjiakan tersebut merupakan suatu upaya untuk melestarikan dan menjaga kelangsungan produk lokal asli Indonesia seperti jamu agar bisa setara dan mendapat pengakuan atas mereknya dari konsumen internasional.

\section{SIMPULAN}

1. Pelindungan hukum atas sumber daya genetik dan pengetahuan tradisional dengan Hak Paten dapat diberikan melalui Undang-Undang No. 13 Tahun 2016 Tentang Paten, khususnya Pasal 26 ayat (1), (2) dan (3). Pelindungan tersebut semakin diperkuat dalam Peraturan Menteri Hukum Dan HAM Republik Indonesia No. 38 Tahun 2018 Tentang Permohonan Paten, yaitu melalui Pasal 24 ayat (1), ayat (2) dan ayat (3).

2. Indonesia dapat mengadaptasi hal yang sama dengan yang sudah dilakukan oleh negara Tiongkok, yaitu dengan memperkenalkan ramuan pengetahuan tradisional dalam wujud pelindungan merek. Di keluarkannya Peraturan Pemerintah Republik Indonesia Nomor 22 Tahun 2018 Tentang Pendaftaran Merek Internasional Berdasarkan Protokol Terkait dengan Persetujuan Madrid Mengenai Pendaftaran Merek Secara Internasional, merupakan suatu langkah pembaharuan hukum yang bertujuan untuk memperkenalkan merek yang berasal dari pengetahuan tradisional Indonesia ke ranah global. Kebjiakan tersebut merupakan suatu upaya untuk melestarikan dan menjaga kelangsungan produk jamu lokal agar bisa setara mendapat kepercayaan dari konsumen internasional.

\section{DAFTAR PUSTAKA}

Churul Aini, Desi. (2010). Telaah Yuridis Ketentuan Pelindungan Pengetahuan Tradisional Dalam Hukum Internasional. Tesis Pascasarjana Hukum Universitas Indonesia, Jakarta. 
Indriyanto, Agung dan Mela Yusnita, Irnie. (2017). Aspek Hukum Pendaftaran Merek. Jakarta: PT. Radja Grafindo.

Koran Kompas, Berita. (2002). Obat dari Bahan Alam Mulai Diteliti. Kompas, 19 September.

Lindsey, Tim, Damian, Eddy, Butt, Simon, dan Suryo Utomo, Tomi. (2006). Hak Kekayaan Intelektual Suatu Pengantar. Bandung: PT Alumni.

Patent Website, European, List of Patent in Japan, http://ep.espacenet.com.

Peraturan Menteri Hukum dan Hak Asasi Manusia Republik Indonesia No. 38 Tahun 2018 Tentang Permohonan Paten.

Peraturan Pemerintah Republik Indonesia Nomor 22 Tahun 2018 Tentang Pendaftaran Merek Internasional Berdasarkan Protokol Terkait dengan Persetujuan Madrid.

Rasjidi, Lili dan Tania Rasjidi, Ira. (2004). Dasar-Dasar Filsafat dan Teori Hukum. Bandung: PT. Alumni.

Sardjono, Agus. (2010). Hak Kekayaan Intelektual dan Pengetahuan Tradisional. Bandung: PT. Alumni.

Undang-Undang Nomor 13 Tahun 2016 Tentang Paten.

Undang-Undang Nomor 20 Tahun 2016 Tentang Merek dan Indikasi Geografis.

Undang-Undang No 5 Tahun 1994 tentang Pengesahan Konvensi Perserikatan Bangsa-Bangsa Mengenai Keanekaragaman Genetic (LN. 1994-41, TLN No. 3556).

WIPO-World Intelectual Property Organization, Definition of Traditional Knowledge, http://wipo.int/tk/en/index html. 